Section Editors

David C. Spencer, MD

Steven Karceski, MD

Steven Karceski, MD

\title{
Gene therapy and muscular dystrophies
}

-

WHAT DID THE RESEARCHERS LEARN? There is a genetic muscle disease in humans called limbgirdle muscular dystrophy (LGMD). In this illness, the affected person has a gene that does not make "sarcoglycan" correctly. Sarcoglycan is a protein in the muscle that helps muscles to function correctly. In their study, which appears in this issue of Neurology ${ }^{\circledR}$, Louise Rodino-Klapac and her colleagues (2008;71:240-247) studied a specific gene treatment. They wanted to find out whether it was possible to inject mice with a gene that contained a new recipe for sarcoglycan. The idea behind their research is simple. Sarcoglycan is an important component of the muscle cell, but when it is made incorrectly it causes muscle weakness. Because there is no known treatment for LGMD, researchers have been looking for ways to "fix" the "broken" gene. This study is just one step in the long process that ultimately may result in the first treatment for this genetic illness. It is considered a translational study.

WHAT IS A TRANSLATIONAL STUDY? Translational studies are critical to the development of medical treatments. The term translational refers to research that bridges the gap between basic research and clinical trials. Basic research often indicates studies that are performed on animals or on cells that are grown in a laboratory. Clinical trials are studies of medical treatment on people. Often there are many steps between basic research studies and clinical trials. However, translational studies are needed to chart the course from animals to humans.

HOW WAS THIS STUDY DONE? In the study, Dr. Rodino-Klapac injected a "correct" copy of the sarco- glycan gene into one of the leg muscles of mice. They allowed the gene to be incorporated into the mouse muscle for either 6 or 12 weeks. After this time, they looked at the muscle to determine whether it was making the "correct" sarcoglycan protein on its own. Using the identical, untreated muscle from the other leg as a comparison, they showed that the treated muscle was making two to two-and-a-half times the usual amount of sarcoglycan. In other words, the treated muscle was making the protein that they wanted it to make.

In addition, they looked at the muscle to see whether there were signs of inflammation. Prior studies had shown that the mouse's immune system was "fighting" the injected gene. This was important to evaluate because it would mean that the body was rejecting that treatment. In other words, even though the treatment was not harmful, the body could not be sure, and it was trying to get rid of the injected gene. In Dr. Rodino-Klapac's study, there was no sign of an inflammation. This was probably because she used a different way to inject the gene than had been tried in earlier studies.

Finally, Dr. Rodino-Klapac was concerned that the treatment would not last. Previous studies had suggested that the sarcoglycan would be made for only a short period of time. In this study, the researchers chose two independent ways of checking how much sarcoglycan was made. Both methods showed that it was produced in good quantities, and the production continued for at least 12 weeks. Here again, the difference between this study and previous studies was in the way that the gene was given. 


\section{About muscular dystrophy}

David C. Spencer, MD

Steven Karceski, MD
WHAT CAUSES MUSCULAR DYSTROPHY? The term muscular dystrophy refers to a group of muscle diseases. There are now more than 30 different kinds of muscular dystrophy. The cause of all of these is genetic. One of many genes can be affected. This is because many genes are needed to make an intricate structure in muscle cells called dystrophin. In other words, muscular dystrophy is a genetic illness due to an error in one or more of the genes responsible for making this complex component of muscle cells.

Dystrophin is made up of proteins and complex sugars. It has two main components: dystroglycan and the sarcoglycan. It is made and used in muscle cells. The exact role of dystrophin is unclear. However, much has been learned about dystrophin. It seems to connect the cell membrane to the cell's skeleton (called a cytoskeleton). In many ways, dystrophin is the substance that anchors the internal structure of the cell, making it stronger and stable.

WHAT HAPPENS TO A PERSON WITH MUSCULAR DYSTROPHY? There are many kinds of muscular dystrophy. Duchenne muscular dystrophy is the most common and most severe type, affecting 1 in 3,500 boys. It is due to a complete lack of dystrophin. It causes progressive muscle weakness which is usually first recognized in early childhood. Most people with Duchenne muscular dystrophy are confined to a wheelchair by adolescence. Because the muscles of breathing are also affected, they usually die at a young age (often in their twenties) from breathing problems.

Becker muscular dystrophy is similar to Duchenne. However, it is milder because people with Becker have some dystrophin, as opposed to none at all in Duchenne. As a result, Becker starts to cause problems later in life. The survival is much longer than in Duchenne. However, people with Becker muscular dystrophy have the same gradual weakening of the muscles of their body.

Another common form of muscular dystrophy is called limb-girdle muscular dystrophy (LGMD). It gets it name from the observation that the illness primarily affects muscles of the shoulder, chest, hip, and thigh. In LGMD, the problem is not that dystrophin is lacking. Instead, the problem is in the gene that controls the production of the sarcoglycan component of dystrophin. Because one component of dystrophin is made incorrectly, the dystrophin cannot work well. It would be like making nuts and bolts, only the bolts are too small, so they do not stay together well.

LGMD can start in childhood, adolescence, or adulthood. As with other types of muscular dystrophy, LGMD gradually gets worse over time. In most people, the weakness occurs over a period of 20 to 30 years before it reaches its most severe stage. In LGMD, because the upper leg muscles are involved, the person may no longer be able to walk long distances. They may need a scooter or wheelchair to get around. Their thinking and personality are unaffected by the illness.

HOW IS LGMD DIAGNOSED? LGMD, as with other forms of muscular dystrophy, is diagnosed in the doctor's office through a careful history and physical examination. Medical testing supports the clinical diagnosis. For instance, in LGMD, blood tests can show an elevated muscle protein called creatine kinase (CK). In LGMD, CK levels can be 5 to 25 times the normal levels. In many people with LGMD, magnetic resonance imaging (MRI) can show the changes that occur in the muscles. Finally, an electromyogram (EMG) is often used to confirm the diagnosis. In this test, a small needle is placed in the muscle to record how well it is working. The kinds of electrical signals the muscle sends back to the recording machine will tell the doctor whether the person has LGMD.

WHAT TREATMENTS ARE AVAILABLE FOR MUSCULAR DYSTROPHY? Currently there are no known treatments for muscular dystrophy. Patients often start a regimen of physical exercises after diagnosis. These are designed to maintain strength and mobility for as long as possible. The exercises definitely help; however, they do not change the course of the illness, which is progressive.

To treat muscular dystrophy, the gene needs to be fixed. Since we do not yet have a way to fix broken genes, researchers are looking at ways to send a "good" gene to the muscle cells. One way is to inject the affected muscle, giving it the "good" gene. How- 
ever, if many muscles are affected, as occurs in muscular dystrophy, this would mean that many injections would be needed. Another way to get the "good" gene to the cells would be to inject it into the bloodstream. However, there are problems with getting the "good" gene past our immune systems.

To get the gene into the cell, researchers use viruses. The viruses have been changed so that they no longer can cause disease. However, some parts of the virus, like the part that allows it to get into the cell, is kept. The "good" gene is packaged into these modified viruses. When the virus goes into the cell, it delivers the "good" gene to the cell's nucleus. The "good" gene is then placed into the gene library. Once there, it can start telling the cell the "correct" recipe for the dystrophin protein. In this way, a genetic illness can be "cured."

The human body, though, is very smart. It can quickly identify foreign substances like viruses. It forms antibodies to protect the body against future viral attacks. When this occurs, white blood cells move to the foreign substance and destroy it. This process is called the inflammatory response.

When a virus is used to deliver a treatment, like a "good" gene, the body might mistake it for the foreign substance it trained itself to recognize and destroy. Since the muscular dystrophy gene is sent to muscle cells (whether injected directly or through the bloodstream), the body might mount a response against the infected muscle cells. Instead of making things better, the situation might get worse because of the body's natural response. This has been one of the concerns of many scientists. It was the reason why Dr. Rodino-Klapac and colleagues looked at the response of mouse muscle cells to the injected "good" gene in this translational study.

WHY ARE TRANSLATIONAL STUDIES IMPORTANT? Although clinical trials may still be some way off, translational studies pave the way for further research. Many genetic illnesses have been identified, but few are treatable. It seems amazing that the structure of DNA was only just described in 1953 by Watson and Crick. Only 55 years later, we are using that information to attempt to fix portions of DNA that are incorrectly written. Using viruses to introduce these genes into cells, studies like that of Dr. Rodino-Klapac show us that it is possible to treat the cause of genetic illnesses like LGMD. Perhaps in the next 50 years, treatment of these illnesses will be as commonplace as prescribed medications are today.

FOR MORE INFORMATION

Muscular Dystrophy Association

http://www.mda.org/ 


\title{
Neurology
}

\author{
Gene therapy and muscular dystrophies \\ Steven Karceski \\ Neurology 2008;71;e6-e8 \\ DOI 10.1212/01.wnl.0000324282.19778.b5
}

This information is current as of July 21, 2008

Updated Information \& Services

Supplementary Material

Subspecialty Collections

Permissions \& Licensing

Reprints including high resolution figures, can be found at:

http://n.neurology.org/content/71/4/e6.full

Supplementary material can be found at:

http://n.neurology.org/content/suppl/2008/11/16/71.4.e6.DC1 http://n.neurology.org/content/suppl/2009/08/27/71.4.e6.DC2

This article, along with others on similar topics, appears in the following collection(s):

\section{All Neuromuscular Disease}

http://n.neurology.org/cgi/collection/all_neuromuscular_disease

Muscle disease

http://n.neurology.org/cgi/collection/muscle_disease

Information about reproducing this article in parts (figures,tables) or in its entirety can be found online at:

http://www.neurology.org/about/about_the_journal\#permissions

Information about ordering reprints can be found online:

http://n.neurology.org/subscribers/advertise

Neurology ${ }^{\circledR}$ is the official journal of the American Academy of Neurology. Published continuously since 1951, it is now a weekly with 48 issues per year. Copyright . All rights reserved. Print ISSN: 0028-3878. Online ISSN: 1526-632X.

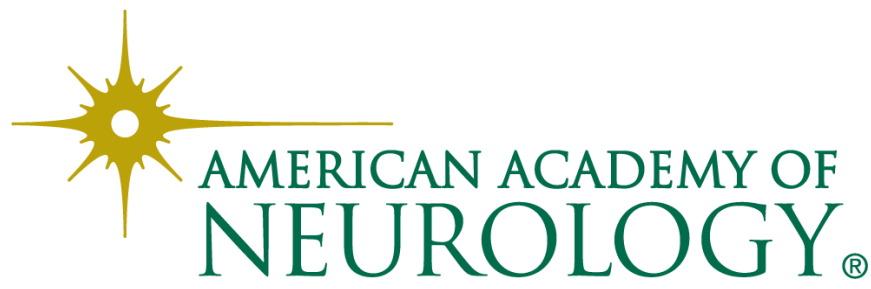

